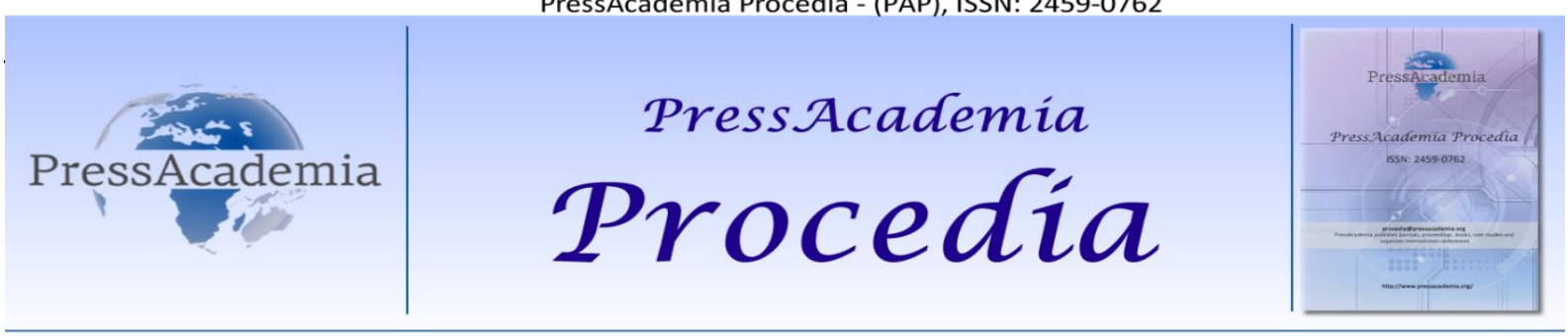

Global Business Research Congress (GBRC), May 24-25, 2017, Istanbul, Turkey.

\title{
THE EFFECT OF AUTHENTIC LEADERSHIP ON ORGANIZATIONAL COMMITMENT AND BURNOUT
}

\author{
DOI: 10.17261/Pressacademia.2017.683 \\ PAP- GBRC-V.3-2017(110)-p.1029-1035 \\ Emel Esen ${ }^{1}$, Kubra Kutluata ${ }^{2}$, Esra Karabulut ${ }^{3}$ \\ ${ }^{1}$ Yıldız Technical University, IIBF, Business Administration Department, istanbul, Turkey. emeloz@yildiz.edu.tr \\ ${ }^{2}$ Y Ildız Technical University, Master Degree Student,istanbul, Turkey. kkutluataa@gmail.com \\ ${ }^{3}$ Y Ildız Technical University, Master Degree Student, İstanbul, Turkey karabulut.esra001@gmail.com
}

\section{To cite this document}

Esen E., Kutluata K., Karabulut. E. (2017). The effect of authentic leadership on organizational commitment and burnout. PressAcademia Procedia (PAP), V.3, p.1029-1035.

Permemant link to this document: http://doi.org/10.17261/Pressacademia.2017.683

Copyright: Published by PressAcademia and limited licenced re-use rights only.

\begin{abstract}
Authentic leadership that reflects the positive focus in positive psychology defines as being aware of their own and others' values/moral perspectives, knowledge, and strengths; aware of the context in which they operate; and authentic leaders are confident, hopeful, optimistic, and resilient, have high moral character. Perceived authentic leader behavior creates high committed and engaged employees to organizations and low employee burnout in the organizations. The main purpose of this study is to understand the effect of authentic leadership on organizational commitment and employees' burnout level. For this purpose, an empirical study was conducted with 144 participants in banking sector. According to the results of this study, if leaders behave authentically to their employees, their followers' commitment level will increase, burnout level will decrease (only for balanced processing dimension of authentic leadership). The study is valuable to understand the meaning of authentic leadership in banking sector and also examine the possible results of leader behavior in the organizations.
\end{abstract}

Keywords: Authentic leadership, organizational commitment, burnout.

JEL Codes: M1, M10, M14

\section{INTRODUCTION}

Authentic leaders in organizations have positive psychological capacities, they are perceived as being aware of their values and moral perspectives, fostering self-regulated positive behaviors and positive self-development (Avolio and Gardner, $2005,321)$. They have relational transparency, moral conduct, balanced processing and self-awareness. They say exactly what they mean, acts in accordance with her/his stated beliefs, seeks out opinions that challenge personal views, asks for feedback to improve interpersonal interactions (Laschinger, Wong and Grau, 2012).

This kind of leadership was found to be associated with major employee outcomes as commitment, organizational citizenship behavior, satisfaction with leaders, and intention to stay. Avolio et al (2004) proposed a model that authentic leadership has a link with followers' attitudes and behaviors (Avolio, 2004, 804). Authentic leaders have abilities to increase the engagement, motivation, commitment, satisfaction, and involvement required from followers to improve their work and performance. In this study, we have determined outcome variables as organizational commitment and burnout. Previous researches have given great deal of attention to organizational commitment in the organization. Mowday, Steers and Porter (1979) conceptualize the strength of the psychological relationship between the individual and the organization in terms of individual's commitment to the organization. Allen and Mayer (1990) differentiated organizational commitment into three components: affective commitment, continuance commitment and normative commitment. Therefore, organizational commitment emphasizes individual's identification and involvement in the organization, it reflects the process by which individuals link themselves to an organization and focuses on the actions of the individuals. On the other hand, Maslach and Jackson (1986) state that burnout is a syndrome of emotional exhaustion, depersonalization, and reduced personal accomplishment that can occur among individuals who work with people in some capacity. Empirical findings suggest that authentic leadership at the individual level has an impact on follower commitment (Clapp-Smith, 
Vogelgesang Avey, 2009, 228). Also, from the leadership theory perspective, it was found that higher levels of authenticity were related to higher engagement (Walumbwa et al., 2010, 203). Some scholars believed that work engagement was simply the opposite of burnout; therefore we demonstrated that authentic leadership and burnout is negatively correlated.

The first part of this study, a theoretical framework about the relationship between authentic leadership, organizational commitment and burnout was stated, and then the research model was provided with research analysis and results.

\section{LITERATURE REVIEW}

\subsection{Authentic leadership}

Luthans and Avolio (2003), define authentic leadership period that relates positive leader capacities and a highly developed organizational matter. The authentic leadership period positively affects self-awareness and self-regulated positive behaviors. The authentic leader is confident, hopeful, optimistic, resilient, ethical, future- oriented, and gives priority to developing relates to be leaders (Illies, P.Morgeson, \& D.Nahrgang, 2005, s. 376). Authentic leadership as a structure of leader behavior that draws on and supports both positive psychological capacities and a positive ethical climate, selfawareness, interiorized_ethical perspective, balanced processing of information, and relational transparency on the part of leaders working with followers, fostering positive self-development (Walumbwa et al., 2008, 94). Moreover, authenticity includes both having one's personal experiences (values, thoughts, emotions and beliefs) and acting in accordance with one's true self (expressing what you really think and believe and behaving accordingly) (Gardner et al., 2005).

\subsection{Components of Authentic Leadership}

\section{a. Self-awareness}

According to Kernis (2003), this component refers to showing an understanding of how one derives and makes meaning of the world and how that meaning making period effects the way one views himself or herself over time. It also refers to showing an under- standing of one's strengths and weaknesses and the all-round nature of the self, which contains achievement cognition into the self through exhibition to others, and being conscious of one's effect on other people (Walumba et.al, 2008,95).

\section{b. Relational Transparency}

This dimension refers to presenting one's authentic self (as opposed to a fake or distorted self) to others. Such behavior encourage trust through uncover that involve openly sharing information and expressions of one's true thoughts and feelings while trying to minimize displays of improper emotions (Walumba et.al, 2008,95).

\section{c. Balanced processing}

According to leaders who show that they objectively analyze all relate data before coming to a decision. Like that leaders also promote views that challenge their deeply held positions (Gardner, et al., 2005,356).

\section{d. Internalized Moral Perspective}

Ryan\& Deci (2003) refers to an internalized and integrated form of self-regulation. This sort of self-regulation is guided by internal moral standards and values versus group, organizational, and societal pressures, and it results in denoted decision making and behavior that is relevant with these internalized values (Avolio et al., 2005; Gardner, et al., 2005).

Authentic behavior refers to actions that lead by the leader's true self as reflected by core values, beliefs, thoughts and feelings, as be against environmental probabilities or obligations from others. Authentic leaders are efficiently and sustainability model for followers through their words and deeds high levels of self-awareness, balanced processing, transparency, and authentic behavior. Thus, as a positive role model, authentic leaders serve as a main input for the development of authentic followers. Authentic leaders and followers, apart from the contributions that authentic members in turn make to improving and continually such a positive organizational climate (Gardner et al., 2005, 347-348). In this study, we have determined two consequences of perceived authentic leadership: organizational commitment and burnout.

Organizational commitment is viewed as the complete of internalized normative impressions to act in a way that collects organizational target and interests (Wiener, 1982, 421). The most extensive approximate to organizational commitment in the literature is one in which commitment is considered an efficient or emotional commitment to the organization like that the powerful committed individual identifies with, is included in, and pleased membership in the organization (Allen and Meyer, 1990, 2). In a model of commitment improved recently by Meyer\&Allen (1987) the three approaches outlined above were labeled 'affective', 'continuance' and 'normative' commitment, respectively. Affective commitment develops firstly from positive job experiments and reflects one's want to remain in the organization. Meyer and Allen (1991) described affective commitment as employee's emotional attachment to, identification with and dependence in the organization. Moreover, Meyer and Herscovitch (2001) proposed that strong affective commitment reflects involvement, shared values and identity (Fernandez and Enache, 2008, 38). Continuance commitment reflects the recognition of costs related with leaving the organization anything that rise perceived costs can be considered an antecedent. The most often studied antecedents have been side bets, or investments, and the validity of alternatives. Normative commitment may also 
improve neverthless when an organization ensures the employee with "rewards" in advance or incurs meaningful costs in providing employment. Recognition of these investments on the part of the organization may build an unbalance in the employee and bring about employees to feel an obligation to mutually by committing themselves to the organization till the debts has been repaid. (Scholl, 1981; Allen and Meyer 1991,72).

The first of all term of burnout that was at the beginning intimate related to the human services for instance health care, education, and social work where employees do 'people' work of some kind, has been extended towards all other professions and occupational groups. Second, burnout research appears to alter towards its reverse: job engagement. Behalf of looking especially to the negative pole, researchers recently expanded their interest to the positive pole of worker's well-being. For this perspective, burnout is restated as an erosion of engagement with the job. This development reflects a trend towards a 'positive psychology' that focuses on human strengths and suitable functioning rather than on weaknesses and defect. (Seligman and Csikszentmihalyi, 2000). Burnout has been defined as a negative reply to stress and viewed as a psychological syndrome come about among individuals and includes of three dimensions: emotional exhaustion, depersonalization, and reduced personal accomplishment (Ha et.al., 2011, 344-345). Emotional exhaustion means to feelings of being emotionally over expanded and exhausted by one's relate with other people who are usually the recipients of one's service or care. Depersonalization means to an unfeeling and dull reply toward these people, who are usually the sensitive's of one's service or care. Reduced personal accomplishment means to a decrease in one's feelings of ability and successful achievement in one's work with people. These three appearance of the burnout syndrome have been the focus of limitless research studies examination the causes and consequences of burnout (Leiter and Maslach, 1988, 297298).

Authentic leadership is entirely related to increased organizational commitment, because of the behavioral pattern of the authentic leader, because it can affirmative effect the behaviors and attitudes of employees, developing commitment, organizational citizenship behaviors and performance (Rego, Lopes and Nascimento, 2013, 136). Authentic leadership is theorized to impact work engagement of followers in the sense of increasing their commitment, satisfaction and energy for work (Alok, 2012, 500). Many scholars show that work engagement was simply the opposite of burnout; therefore we demonstrated that authentic leadership and burnout is negatively correlated. The role of leadership in creating work environment can decrease the development of employee burnout (Laschinger, 2013, 4).

\section{DATA AND METHODOLOGY}

The purpose of this study is to examine within 144 employees of banking organizations the effects of authentic leadership on organizational commitment and employees' burnout level. The main hypotheses reflects that employees who believe that he or she perceive their leaders as authentic are likely to have higher level of commitment and lower level of burnout.

\subsection{Participants}

Demographics of the sample are presented in Table 1. The majority of the respondents are male (\%54), between 31-40 ages $(\% 52)$, married (\%54), have 5-9 years total tenure (\%44), have 0-4 years at current organization (\%47).

Table 1: Demographic Statistics of Participants

\begin{tabular}{|l|l|c|c|}
\hline & & Frequency & Percent (\%) \\
\hline \multirow{3}{*}{ Age } & $\mathbf{2 1 - 3 0}$ & 69 & 48 \\
\cline { 2 - 4 } & $\mathbf{3 1 - 4 0}$ & 75 & 52 \\
\hline \multirow{3}{*}{ Gender } & Male & 78 & 54 \\
\cline { 2 - 4 } & Female & 66 & 46 \\
\hline \multirow{5}{*}{ Total tenure } & Married & 78 & 54 \\
\cline { 2 - 4 } & Single & 66 & 46 \\
\hline \multirow{5}{*}{ Tenure } & $\mathbf{0 - 4}$ years & 43 & 30 \\
\cline { 2 - 4 } & $\mathbf{5 - 9}$ & 64 & 44 \\
\cline { 2 - 4 } & $\mathbf{1 0 - 1 4}$ & 33 & 23 \\
\cline { 2 - 4 } & $\mathbf{1 5 - 1 9}$ & 4 & 3 \\
\cline { 2 - 4 } & $\mathbf{0 - 4}$ years & 67 & 47 \\
\cline { 2 - 4 } & $\mathbf{5 - 9}$ & 62 & 43 \\
\cline { 2 - 4 } & $\mathbf{1 0 - 1 4}$ & 13 & 9 \\
\cline { 2 - 4 } & $\mathbf{1 5 - 1 9}$ & 2 & 1 \\
\hline
\end{tabular}

\subsection{Measures}

To test the hypothesized model, participants completed measures that addressed authentic leadership, organizational commitment and employee burnout. Demographic information was also requested.

Authentic leadership measurement 
The Authentic Leadership Questionnaire (ALQ) (Avolio et al. 2007) was used to measure with 16 items. The ALQ is divided into four subscales, based on the four authentic components: relational transparency, balanced processing, self-awareness, and internalized moral perspective.

\section{Organizational commitment measurement}

The 15-item Organizational Commitment Questionnaire developed by Meyer and Allen (1997) was used to measure organizational commitment with three dimensions (affective commitment, continuance commitment and normative commitment)

\section{Burnout level measurement}

The 22-item Maslach Burnout Inventory developed by Maslach and Jackson was used to measure burnout syndrome. Items in the $\mathrm{MBI}$ inventory are grouped into the three dimensions of emotional exhaustion, depersonalization and personal accomplishment.

\subsection{Data Analysis}

The data was analyzed in SPSS 18.0. Descriptive statistics (i.e., frequency distributions, means and standard deviations) were used to develop a profile of the respondents and to summarize the variables. Alpha coefficients were also computed to assess the reliability of authentic leadership, organizational commitment and burnout. To better understand the effect of authentic leaders on dependent variables, regression analysis was performed.

\section{FINDINGS AND DISCUSSIONS}

The results are presented in following sections. Reliability analysis and descriptive statistics are showed in first section. The second section includes the correlation results of variables and simple regression analysis results.

For the reliability analysis of the scale used in this study, the most frequently used Cronbach alpha coefficiency was examined. The Cronbach alpha coefficiency of the scale in this study is higher than the commonly accepted .60 as shown in Table 2.

\section{Table 2: Reliability Scores for Dimensions and Sub-Dimensions}

\begin{tabular}{|l|c|}
\hline Authentic leadership &, 884 \\
\hline Relational transparency &, 618 \\
\hline Balanced processing &, 802 \\
\hline Internalized moral perspective &, 716 \\
\hline Self- awareness &, 798 \\
\hline Organizational commitment &, 786 \\
\hline Affective commitment &, 874 \\
\hline Normative commitment &, 648 \\
\hline Continuance commitment &, 674 \\
\hline Burnout &, 804 \\
\hline Emotional exhaustion &, 817 \\
\hline Depersonalization &, 630 \\
\hline Personal accomplishment &, 657 \\
\hline
\end{tabular}

The cronbach alpha value of authentic leadership was found as ,884; organizational commitment was found as,786 and burnout was found as, 804 .

According to the results of the descriptive statistics, mean and standard deviation for the authentic leadership, organizational commitment and burnout were found as $3,67 / 5 ; 3,00 / 5$ and $2,90 / 5$. Details about dimensions and sub dimensions were also presented in Table 3.

Table 3: Descriptive Statistics

\begin{tabular}{|l|c|c|}
\hline & Mean & Std. Deviation \\
\hline Authentic leadership & 3,6788 &, 60233 \\
\hline Relational transparency & 3,8861 &, 58257 \\
\hline Internalized moral perspective & 3,5938 &, 70950 \\
\hline Balanced processing & 3,6227 &, 95692 \\
\hline Self- awareness & 3,5469 &, 79880 \\
\hline Organizational commitment & 3,0097 &, 55660 \\
\hline Affective commitment & 3,1701 &, 89687 \\
\hline Normative commitment & 2,9375 &, 72209 \\
\hline Continuance commitment & 2,8750 &, 66306 \\
\hline
\end{tabular}




\begin{tabular}{|l|c|c|}
\hline Burnout & 2,9015 &, 43449 \\
\hline Emotional exhaustion & 2,6829 &, 73444 \\
\hline Depersonalization & 3,5286 &, 46318 \\
\hline Personal accomplishment & 2,1056 &, 66646 \\
\hline
\end{tabular}

In Table 4, correlation results between variables were presented. The highest correlations can be seen between authentic leadership and self-awareness $(r=, 845)$. There is no correlation between authentic leadership and organizational commitment, but authentic leadership is correlated with sub dimension of organizational commitment as continues commitment. Also, balanced processing is correlated with organizational commitment. Authentic leadership and burnout are negatively correlated $(r=-, 174)$.

\section{Table 4: Correlation Results of Variables}

\begin{tabular}{|c|c|c|c|c|c|c|c|c|c|c|c|c|}
\hline & 1 & 2 & 3 & 4 & 5 & 6 & 7 & 8 & 9 & 10 & 11 & 12 \\
\hline \begin{tabular}{|l|} 
Authentic \\
leadership
\end{tabular} & 1 & & & & & & & & & & & \\
\hline \multirow{2}{*}{\begin{tabular}{|l|} 
Relational \\
transparency
\end{tabular}} &, $791^{* *}$ & 1 & & & & & & & & & & \\
\hline & ,000 & & & & & & & & & & & \\
\hline \multirow{2}{*}{$\begin{array}{l}\text { Internalized } \\
\text { moral perspective }\end{array}$} &, $806^{* *}$ & $600^{* *}$ & 1 & & & & & & & & & \\
\hline & ,000 & ,000 & & & & & & & & & & \\
\hline \multirow{2}{*}{\begin{tabular}{|l|} 
Balanced \\
processing
\end{tabular}} &, $817^{* *}$ &, $480^{* *}$ &, $510^{* *}$ & 1 & & & & & & & & \\
\hline & , 000 & ,000 & ,000 & & & & & & & & & \\
\hline \multirow[t]{2}{*}{ Self- awareness } & $845^{* *}$ & $510^{* *}$ &, $537^{* *}$ & ,676 & 1 & & & & & & & \\
\hline & , 000 & ,000 & 000 & 000 & & & & & & & & \\
\hline \multirow{2}{*}{\begin{tabular}{|l|}
$\begin{array}{l}\text { Organizational } \\
\text { commitment }\end{array}$ \\
\end{tabular}} & , 146 & 087 &, $230^{* *}$ & 074 & 089 & 1 & & & & & & \\
\hline & 082 & ,298 & ,005 & 378 & 291 & & & & & & & \\
\hline \multirow{2}{*}{\begin{tabular}{|l|} 
Affective \\
commitment
\end{tabular}} & ,116 & 082 &, $181^{*}$ & 054 & 065 & $835^{* *}$ & 1 & & & & & \\
\hline & , 167 & 326 & 030 &, 520 & ,440 & , 000 & & & & & & \\
\hline \multirow{2}{*}{\begin{tabular}{|l|} 
Normative \\
commitment
\end{tabular}} & 003 &,- 006 &,- 016 &, 020 & 010 & $358^{* *}$ &,- 118 & 1 & & & & \\
\hline & ,976 & ,941 & 851 & 816 & ,909 & , 000 & , 157 & & & & & \\
\hline \multirow{2}{*}{$\begin{array}{l}\text { Continuance } \\
\text { commitment }\end{array}$} & $177^{*}$ & 092 & $299^{* *}$ & 082 & ,110 &, $850^{* *}$ &, $584^{* *}$ &, $222^{* *}$ & 1 & & & \\
\hline & 034 & 274 & , 000 & 331 & ,191 & , 000 & ,000 & ,007 & & & & \\
\hline \multirow[t]{2}{*}{ Burnout } &,$- 174^{*}$ & \begin{tabular}{|l|}
-044 \\
\end{tabular} &,- 072 & ,239** &,$- 205^{*}$ &,$- 184^{*}$ & $334^{* *}$ &, $225^{* *}$ & $\begin{array}{r}- \\
, 117\end{array}$ & 1 & & \\
\hline & ,037 & ,597 & ,392 &, 004 & ,014 & ,027 & 000 & ,007 & 161 & & & \\
\hline \multirow[t]{2}{*}{\begin{tabular}{|l|} 
Emotional \\
exhaustion
\end{tabular}} &,- 146 &,- 025 &,- 098 & $214^{* *}$ &,- 138 & $247^{* *}$ & $441^{*}$ &, $293^{* *}$ & , 162 &, $898^{* *}$ & 1 & \\
\hline &, 080 & ,762 & 241 & ,010 & 099 & ,003 & 000 & , 000 & 052 & ,000 & & \\
\hline \multirow{2}{*}{\begin{tabular}{|l} 
Personal \\
accomplishment
\end{tabular}} &,- 027 & 024 & 081 &,- 059 &,- 122 & 077 & ,117 &,- 063 & ,058 &, $481^{* *}$ & ,113 & 1 \\
\hline & ,749 & ,777 & ,335 & ,483 & ,146 & ,358 & ,162 & ,456 & ,487 & , 000 & , 179 & \\
\hline \multirow[t]{2}{*}{ Depersonalization } &, $241^{* *}$ & \begin{tabular}{l|l|}
-114 \\
\end{tabular} &,$- 203^{*}$ &, $251^{* *}$ &, $217^{* *}$ &, $226^{* *}$ & $386^{* *}$ &, $243^{* *}$ & ,154 &, $793^{* *}$ & $801^{* *}$ & ,014 \\
\hline & ,004 & 175 & 015 &, 002 & 009 & 006 & 000 & ,003 & 066 & ,000 & , 000 & 864 \\
\hline
\end{tabular}

\subsection{Test of hypothesized model}

Table 5, 6 and 7 present the simple and multiple regression analysis results in order to the test the hypotheses.

Table 5: Results of Multiple Regression Analysis

\begin{tabular}{|c|c|c|c|c|c|}
\hline & Sum of Squares & Degrees of Freedom & Mean Square & $\mathbf{F}$ & Sig. \\
\hline Regression & 2,584 & 4 & 646 & 2,153 & ,048 \\
\hline Residual & 41,718 & 139 & ,300 & & \\
\hline Total & 44,302 & 143 & & & \\
\hline \multicolumn{6}{|l|}{$\mathrm{R}^{2}:, 058$} \\
\hline \multicolumn{3}{|c|}{ Standardized coefficients } & $\mathrm{t}$ & Sig. & \\
\hline \multicolumn{2}{|c|}{ Relational transparency } &,- 066 &,- 609 & & ,543 \\
\hline \multicolumn{2}{|c|}{ Internalized moral perspective } & ,294 & 2,662 & &, 009 \\
\hline \multicolumn{2}{|c|}{ Balanced processing } &,- 037 &,- 323 & & ,747 \\
\hline \multicolumn{2}{|c|}{ Self- awareness } &,- 011 &,- 088 & & ,930 \\
\hline
\end{tabular}

Dependent variable: Organizational commitment 
The results of simple regression analysis shows that authentic leadership have no effect on overall organization commitment, therefore we look at the effects of sub dimensions of authentic leadership on organizational commitment. Table 5 summarizes that only one dimension of authentic leadership as internalized moral perspective has an impact on organizational commitment $(p=, 009 ; \beta=, 294)$.

Table 6: Results of Simple Regression Analysis

\begin{tabular}{|c|c|c|c|c|c|}
\hline & Sum of Squares & Degrees of Freedom & Mean Square & $\mathbf{F}$ & Sig. \\
\hline Regression & ,817 & 1 & ,817 & 4,430 & 037 \\
\hline Residual & 26,179 & 142 & 300 & & \\
\hline Total & 26,996 & 143 & & & \\
\hline \multicolumn{6}{|l|}{$R^{2}:, 058$} \\
\hline \multicolumn{3}{|c|}{ Standardized coefficients } & $\mathrm{t}$ & \multicolumn{2}{|l|}{ Sig. } \\
\hline Authentic I & &,- 174 & $-2,105$ & & 037 \\
\hline
\end{tabular}

Dependent variable: Burnout

The results of multiple regression analysis shows that authentic leadership have effect on employees' burnout level ( $p=, 037, \beta=-, 174)$ in Table 6 . Also, the effects of subdimensions of authentic leadership were analyzed in Table 7.

Table 7: Result of Multiple Regression Analysis

\begin{tabular}{|c|c|c|c|c|c|}
\hline & Sum of Squares & Degrees of Freedom & Mean Square & $\mathbf{F}$ & Sig. \\
\hline Regression & 1,965 & 4 & ,491 & 2,728 & 032 \\
\hline Residual & 25,031 & 139 & , 180 & & \\
\hline Total & 26,996 & 143 & & & \\
\hline \multicolumn{6}{|l|}{$\mathrm{R}^{2}:, 270$} \\
\hline \multicolumn{3}{|c|}{ Standardized coefficients } & $\mathrm{t}$ & \multicolumn{2}{|l|}{ Sig. } \\
\hline \multicolumn{2}{|c|}{ Relational transparency } & ,098 & 920 & & ,359 \\
\hline \multicolumn{2}{|c|}{ Internalized moral perspective } & 055 & ,502 & & ,616 \\
\hline \multicolumn{2}{|c|}{ Balanced processing } &,- 225 & $-1,955$ & & ,043 \\
\hline \multicolumn{2}{|c|}{ Self- awareness } &,- 133 & $-1,129$ & & ,261 \\
\hline
\end{tabular}

Dependent variable: Burnout

Only one dimension of authentic leadership as balanced processing has effect on employees' burnout $(p=, 043 ; \beta=-, 225)$.

\section{CONCLUSION}

The main purpose of this study is to understand the influence of authentic leadership on employee outcomes as organizational commitment and employee burnout. The main hypotheses propose that if leaders behave authentically to their followers, this kind of leadership type creates more committed and engaged employees and low burnout level. For this purpose, an empirical study was conducted to understand the relations between research variables. The sample consists of 144 employees from banking sectors.

Authentic leadership was defined with relational transparency, balanced processing, internalized moral perspective and self-awareness. According to the results of the study, the highest mean value can be seen for relational transparency. Organizational commitment was also defined with affective commitment, normative commitment and continuance commitment. Mean value for affective commitment is higher among other subdimensions. And lastly, emotional exhaustion, depersonalization and persona accomplishment are subdimensions of burnout. Depersonalization was higher from other dimensions. According to the hypothesis testing results, only internalized moral perspective have effect on organizational commitment. This results show that if leaders internalize moral values and reflects them to their behaviors, their employees identified themselves with their organizations. On the other hand, balanced processing have negative effect on employees' burnout. While leaders are trying to objectively analyze the all information about decision, their behavior can increase followers' burnout.

The study is valuable to understand the meaning of authentic leadership in banking sector and also examine the possible results of leader behavior in the organizations.

It makes contribution to current literature about the possible effects of perceived authentic leadership on possible employee outcomes. For further studies, many sectors can select to make comparisons about authentic leadership type; also antecedents can be determined to understand why leaders behave authentically and what the results are. 


\section{REFERENCES}

Allen, N. J., \& Meyer, J. P., "The measurement and antecedents of affective, continuance and normative commitment to the organization", Journal of occupational psychology, 63(1), (1990): 1-18.

Allen, N. J., \& Meyer, J. P, "A Three-Component Conceptualization Of Organizational Commitment", Human Resource Management Review, 1, 1, (1991): 61-89.

Alok, K., \& Israel, D., “Authentic leadership \& work engagement”, Indian Journal of Industrial Relations, (2012): $498-510$.

Avolio B.J., Gardner W.L., "Authentic Leadership Development:Getting to the root of positive forms of leadership", The leadership quarterly, 16, (2005): 315-338.

Avolio B.J., Gardner W.L. \& Walumbwa F.O., “Authentic Leadership Questionnaire”, Retrieved from http:// www.mindgarden.com (2007)

Avolio, B. J., Gardner, W. L., Walumbwa, F. O., Luthans, F., \& May, D. R. ,“Unlocking the mask: A look at the process by which authentic leaders impact follower attitudes and behaviors", The leadership quarterly, 15(6), (2004): 801-823.

Clapp-Smith, R., Vogelgesang, G. R., \& Avey, J. B., “Authentic leadership and positive psychological capital the mediating role of trust at the group level of analysis", Journal of Leadership \& Organizational Studies, 15(3), (2009): 227-240.

Fernandez, V., \& Enache, M. , “Exploring the relationship between protean and boundaryless career attitudes and affective commitment through the lens of a fuzzy set QCA methodology", Intangible Capital, 4(1), (2008): 31-66.

Gardner, W. L., Avolio, B. J., Luthans, F., May, D. R., \& Walumbwa, F. “Can you see the real me?” A self-based model of authentic leader and follower development", The Leadership Quarterly, 16(3), (2005): 343-372.

$\mathrm{Ha}$, Jae-Pil, Kristi M. King, and Dylan J. Naeger, "The Impact of Burnout on Work Outcomes among South Korean Physical Education Teachers", Journal of Sport Behavior, Vol. 34, No. 4, (2011): 343-357.

Ilies, R., Morgeson, F. P., \& Nahrgang, J. D., “Authentic leadership and eudaemonic well-being: Understanding leader-follower outcomes", The Leadership Quarterly, 16(3), (2005): 373-394.

Laschinger, H. K. S., Wong, C. A., \& Grau, A. L, “The influence of authentic leadership on newly graduated nurses' experiences of workplace bullying, burnout and retention outcomes: A cross-sectional study", International journal of nursing studies, 49(10), (2012): 1266-1276.

Leiter, M. P., \& Maslach, C., "The impact of interpersonal environment on burnout and organizational commitment", Journal of organizational behavior, 9(4), (1988): 297-308.

Maslach, C., Jackson, S. E., \& Leiter, M. P. Maslach Burnout Inventory, Palo Alto, 1986.

Maslach, C., \& Jackson, S. E., "The measurement of experienced burnout", Journal of organizational behavior, 2(2), (1981): 99-113.

Meyer JP, Allen NJ. “Commitment in the workplace: theory, research, and application”, Thousand Oaks: Sage; 1997.

Meyer, J. P., \& Herscovitch, L. "Commitment in the workplace: Toward a general model”, Human resource management review, 11(3), (2001):299-326.

Mowday, R. T., Steers, R. M., \& Porter, L. W. "The measurement of organizational commitment", Journal of vocational behavior, 14(2), (1979): 224-247.

Rego, P., Lopes, M. P., \& Nascimento, J. L. "Authentic leadership and organizational commitment: The mediating role of positive psychological capital", Journal of Industrial Engineering and Management, 9(1), (2016): 129.

Seligman, M. E., \& Csikszentmihalyi, M. "Special issue on happiness, excellence, and optimal human functioning", American Psychologist, 55(1), (2000): 5-183.

Scholl, R. W. "Differentiating organizational commitment from expectancy as a motivating force", Academy of management Review, 6(4), (1981): 589-599.

Walumbwa, F. O., Avolio, B. J., Gardner, W. L., Wernsing, T. S., \& Peterson, S. J. Authentic leadership: Development and validation of a theory-based measure + . Journal of management, 34(1), (2008): 89-126.

Walumbwa, F. O., Wang, P., Wang, H., Schaubroeck, J., \& Avolio, B. J. Psychological processes linking authentic leadership to follower behaviours. Leadersh Q, 21 (5), (2010): 901-914.

Wiener, Y. Commitment in organizations: A normative view, Academy of management review, 7(3), (1982): $418-428$. 